Running Header: Willacker et al. Mercury in Western Reservoirs

\title{
Reservoirs and Water Management Influences on Fish Mercury Concentrations in the Western United States and Canada
}

James J. Willacker ${ }^{1 *}$, Collin A. Eagles-Smith ${ }^{1}$, Michelle A. Lutz ${ }^{2}$, Michael T. Tate ${ }^{2}$, Jesse M. Lepak $^{3}$ and Joshua T. Ackerman ${ }^{4}$

${ }^{1}$ U.S. Geological Survey, Forest and Rangeland Ecosystem Science Center, 3200 SW Jefferson Way, Corvallis, OR 97331, USA

${ }^{2}$ U.S. Geological Survey, Wisconsin Water Science Center, 8505 Research Way, Middleton, WI 53562, USA

${ }^{3}$ Colorado Parks and Wildlife, 317 West Prospect Rd., Fort Collins, CO 80526, USA

${ }^{4}$ U.S. Geological Survey, Western Ecological Research Center, Dixon Field Station, 800

Business Park Drive, Suite D, Dixon, CA, 95620, USA

*Corresponding author: e-mail: jwillacker@usgs.gov; phone: (541) 750-0957 


\begin{abstract}
:
Anthropogenic manipulation of aquatic habitats can profoundly alter mercury $(\mathrm{Hg})$ cycling and bioaccumulation. The impoundment of fluvial systems is among the most common habitat manipulations and is known to increase fish $\mathrm{Hg}$ concentrations immediately following impoundment. However, it is not well understood how $\mathrm{Hg}$ concentrations differ between reservoirs and lakes at large spatial and temporal scales or how reservoir management influences fish $\mathrm{Hg}$ concentrations. This study evaluated total $\mathrm{Hg}(\mathrm{THg}$ ) concentrations in 64386 fish from 883 reservoirs and 1387 lakes, across the western United States and Canada, to assess differences between reservoirs and lakes, as well as the influence of reservoir management on fish $\mathrm{THg}$ concentrations. Fish THg concentrations were 1.4-fold higher in reservoirs $(0.13 \pm 0.011 \mu \mathrm{g} / \mathrm{g}$ wet weight \pm standard error) than lakes $(0.09 \pm 0.006)$, though this difference varied among ecoregions. Fish THg concentrations were 1.5- to-2.6 fold higher in reservoirs than lakes of the North American Deserts, Northern Forests, and Mediterranean California ecoregions, but did not differ between reservoirs and lakes in four other ecoregions. Fish THg concentrations peaked in three-year-old reservoirs then rapidly declined in 4-12 year old reservoirs. Water management was particularly important in influencing fish $\mathrm{THg}$ concentrations, which were up to 11-times higher in reservoirs with minimum water storage occurring in May, June, or July compared to reservoirs with minimum storage occurring in other months. Between-year changes in maximum water storage strongly influenced fish THg concentrations, but within-year fluctuations in water levels did not influence fish $\mathrm{THg}$ concentrations. Specifically, fish $\mathrm{THg}$ concentrations increased up to 3.2-fold over the range of between-year changes in maximum water storage in all ecoregions except Mediterranean California. These data highlight the role of reservoir creation and management in influencing fish $\mathrm{THg}$ concentrations and suggest that water management may provide an effective means of mitigating $\mathrm{Hg}$ bioaccumulation in some reservoirs.
\end{abstract}

Keywords: Lakes; Methylmercury; Post-impoundment; Season; Water Level Fluctuation; Western North America Mercury Synthesis 


\section{Introduction}

Mercury $(\mathrm{Hg}$ ) contamination is globally ubiquitous in aquatic ecosystems (Driscoll et al., 2013). Western North America presents a particularly heterogeneous landscape of diverse $\mathrm{Hg}$ sources from legacy mining and atmospheric deposition, coupled with extreme gradients in habitats and environmental conditions (Eagles-Smith et al., 2016b). The aridity gradient in western North America has fostered widespread human modification of aquatic environments, which influence $\mathrm{Hg}$ risk because of associated alterations to complex biogeochemical and ecological processes that regulate the production and bioaccumulation of methylmercury (MeHg), the most common and toxic form of $\mathrm{Hg}$ in biota (Clarkson and Magos, 2006). This is important because $\mathrm{MeHg}$ production can influence $\mathrm{Hg}$ concentrations in biota more than total inorganic Hg inputs in some systems (Benoit et al., 2003; Suchanek et al., 2008; Wiener et al., 1990). Reservoir creation, and associated hydrologic management, are among the most widespread anthropogenic modifications of aquatic ecosystems, and may influence $\mathrm{Hg}$ cycling and $\mathrm{MeHg}$ bioaccumulation at a global scale (Rosenberg et al., 2000).

The modern development of western North America was made possible by impounding waterways to create reservoirs for water storage, irrigation, flood control, and hydropower (Travis, 2003). There are nearly 23000 dams in the western United States (Graf, 1999) that are capable of storing almost 6 times the mean annual runoff of the region (Sabo et al., 2012; Sabo et al., 2010). Although dams provide many social and economic benefits to society, impounding natural waters fundamentally alters the functioning of riverine ecosystems. Impoundment changes geomorphological processes, both in the inundated reach and downstream (Kingsford, 2000; Sabo et al., 2012); biogeochemical processes such as organic carbon transport, nutrient inputs, and oxygenation (Friedl and Wüest, 2002); and ecological processes such as community composition, ecosystem productivity, and bioenergetics (Bunn and Arthington, 2002; Ligon et al., 1995). Thus, the semi-fluvial nature of reservoirs coupled with their manipulated hydrologic cycles make reservoirs unique from most non-impounded lakes (Friedl and Wüest, 2002; Hall et al., 2005). All of these processes play fundamental roles in the distribution, methylation, and bioaccumulation of $\mathrm{Hg}$ (Hall et al., 2005), and thus may result in differences in $\mathrm{Hg}$ cycling between reservoirs and non-impounded lakes. 
The influence of reservoir creation on mercury cycling, frequently referred to as the 'reservoir effect' (Bodaly et al., 1984; Jackson, 1988; Stewart et al., 2008), is a well-documented phenomenon (Bodaly et al., 1984; Hall et al., 2005; Hecky et al., 1991; Lodenius et al., 1983; St. Louis et al., 2004; Verta et al., 1986) resulting in elevated MeHg concentrations in biota following reservoir impoundment. These increases in biotic $\mathrm{MeHg}$ concentrations have largely been attributed to enhanced microbial methylation of inorganic $\mathrm{Hg}$ resulting from inundation of terrestrial organic matter and favorable redox conditions in flooded soils (Bodaly et al., 1984; Friedl and Wüest, 2002; Hall et al., 2005; Lucotte et al., 1999). Thus, factors that influence the quantity and quality of organic matter or the prevalence of anoxia result in substantial variation in the magnitude and duration of increases in $\mathrm{MeHg}$ concentrations after reservoir creation (Hall et al., 2005; Johnston et al., 1991; Larssen, 2010; Verta et al., 1986). Even after the initial pulse of $\mathrm{MeHg}$ production associated with reservoir creation, the structure and management of reservoirs continue to influence $\mathrm{Hg}$ cycling (Caldwell et al., 2000; Eckley et al., 2015; Hall et al., 2005). Despite the established influence of reservoir creation on fish $\mathrm{MeHg}$ concentrations, relatively little is known about how reservoir management influences fish $\mathrm{Hg}$ concentrations, nor how these contamination levels differ from more natural lake ecosystems across large landscapes.

The hydrologic cycles of reservoirs are highly managed and dependent on the purpose of each reservoir. As a result, many reservoirs experience substantial water level fluctuations, with widely different timing and duration (Grigg, 1996; Poff and Hart, 2002). For example, reservoirs managed for flood control are often maintained at low water levels, but experience large fluctuations during precipitation events, whereas reservoirs managed for other purposes may have more stable water levels (Eckley et al., 2015; Poff and Hart, 2002). This is important, because repeated wetting and drying of sediments associated with water level management may further stimulate methylation of inorganic $\mathrm{Hg}$ (Eckley et al., 2015; Snodgrass et al., 2000). However, the magnitude of this effect is likely dependent upon the extent, timing, and duration of water level fluctuations. Three sediment regions are associated with water level fluctuations; 1) permanently inundated sediments, 2) sediments exposed to the atmosphere for relatively short ( $\leq 1$ year) periods, and 3 ) sediments exposed for longer (> 1 year) periods, but still periodically inundated. Exposure of sediments for longer periods may be especially important for $\mathrm{MeHg}$ production due to associated increases in sediment re-oxidation and colonization by early 
successional vegetation, which stimulate $\mathrm{MeHg}$ production upon re-inundation (Larson et al., 2014; Selch et al., 2007; Snodgrass et al., 2000; Sorensen et al., 2005). Further, identifying the effects of between- versus within-year water level fluctuations on fish THg concentrations may be particularly valuable in understanding, and adaptively managing, the impacts of extended droughts, which have become increasingly common in western North America.

Broad, landscape-scale studies that compare $\mathrm{Hg}$ concentrations in fish from reservoirs to those from non-impounded lakes are limited due to the difficulty of comparing impoundments in differing stages of development to natural lakes (Depew et al., 2013a; Depew et al., 2013b; but see Kamman et al., 2005; and Monson et al., 2011). Further, it is unclear how contemporary water management influences $\mathrm{Hg}$ concentrations in reservoirs. Thus, an extensive dataset of $\mathrm{Hg}$ concentrations in fish from reservoirs and non-impounded lakes across the western United States and Canada was compiled to test whether $\mathrm{Hg}$ concentrations in fish differed between reservoirs and non-impounded lakes across this broad geographical area. Additionally, the influence of reservoir age and water management practices on fish $\mathrm{Hg}$ concentrations was assessed.

\section{Materials and Methods}

\subsection{Mercury Data Compilation}

Fish total mercury (THg) concentration data from reservoirs and lakes were compiled from a variety of existing sources including: monitoring programs, non-routine surveys, and government and academic research projects occurring in the western United States and Canada (Eagles-Smith et al., 2016a; Figure S1). The resulting dataset included data collected with a variety of analytical methods during a period of over four decades (1969-2011). Although analytical technology has developed considerably over this period, data were not excluded based on analytical method or analysis date since these changes impact analytical precision rather than accuracy. Data were screened to remove duplicate records, georeferenced, and all collection locations from a waterbody were aggregated into a single point at the centroid of each lake or reservoir (see Eagles-Smith et al., 2016a this issue for details). Each waterbody was also classified into Level I ecoregions (Omernik and Griffith, 2014; www.epa.gov/wed/pages/ecoregions.html; Figure S1). Fish $\mathrm{THg}$ concentrations were standardized to $\mu \mathrm{g} / \mathrm{g}$, and all concentrations converted to wet weight THg concentrations ( $\mu \mathrm{g} / \mathrm{g}$ ww) either using the sample-specific moisture content (when 
reported) or the mean moisture content of fish (76\%) across all available samples when moisture content was not reported. Whole body $\mathrm{THg}$ concentrations were converted to equivalent $\mathrm{THg}$ concentrations for skinless, boneless fillets by dividing by 0.74 , the average ratio of whole body to muscle THg concentrations for individual fish (Bevelhimer et al., 1997; Boalt et al., 2014; Goldstein et al., 1996). All fish lengths were standardized to fork length (cm) using species specific fork length-to-total length or fork length-to-standard length ratios reported in FishBase (Froese and Pauly, 2003). Any records that had ambiguous locations, tissue types, or length types were removed prior to analysis.

To account for the substantial range of fish sizes represented in the dataset, individual fish THg concentrations were size adjusted to the concentration at the median lengths of each species, except when a likelihood ratio test suggested that length was not correlated with $\mathrm{THg}$ concentrations in a particular species. To facilitate size adjustment in underrepresented species, related species with similar ecological and physiological characteristics were grouped (Table S1). For each species group, THg concentrations of individual fish were predicted at the median length for that species (i.e., not the median length of the species group; Table S1) using linear mixed-effect models (e.g., one for each species group) with fork length as a fixed covariate and waterbody, species, and a species $\times$ fork length interaction as random effects. These models were developed with a larger fish $\mathrm{Hg}$ dataset including fish from all habitats in the western United States and Canada (i.e., not just lakes and reservoirs; Eagles-Smith et al., 2016a this issue). The residuals were then added back to the median-length predicted $\mathrm{THg}$ concentrations to calculate the $\mathrm{THg}$ concentrations for individual fish.

\subsection{Reservoir Data Compilation}

Waterbodies were identified as lakes or reservoirs and wetlands, streams, rivers, and canals excluded, using the National Hydrology Dataset (NHD; http://nhd.usgs.gov/data.html) in the U.S. and the National Hydro Network (NHN;

http://www.geobase.ca/geobase/en/data/nhn/description.html) in Canada. Waterbodies with known point-source industrial impacts (e.g., chlor-alkali facilities) were not included in the dataset. The U.S. Army Corps of Engineers National Inventory of Dams (NID; http://nid.usace.army.mil), Atlas of Canada Dams Data (http://www.nrcan.gc.ca/earthsciences/geography/atlas-canada), NHN Manmade Features data, and the Global Reservoir and 
Dam database (GRanD; http://www.gwsp.org/products/grand-database.html) were used to further distinguish impounded from non-impounded waterbodies. Any waterbody with an inventoried dam was designated a reservoir, whereas lentic waterbodies without an inventoried dam were designated as non-impounded lakes (hereafter, lakes). Lakes with low weirs that passively stabilize natural water levels were not considered impounded.

To examine the influence of water management, specifically the magnitude and seasonality of water level fluctuations in reservoirs, in-situ reservoir storage (volume) data was obtained for a subset of reservoirs from the U.S. Bureau of Reclamation (BOR), Army Corps of Engineers (ACOE), and California Data Exchange Center (CDEC; Table 1). Storage is monitored continuously in each reservoir using sensors that convert real-time water level measurements to volume using the elevation-volume curves established for each reservoir (US Bureau of Reclemation, 2001). For each reservoir, monthly mean reservoir storage was extracted for all water years between 1964 (or earliest record) and 2015, and standardized to cubic kilometers $\left(\mathrm{km}^{3}\right)$ units. Because the collection intervals (i.e., every 15 minutes, 1 hour, 6 hour, or 24 hrs), completeness, and quality of these data varied considerably among data sources and waterbodies, a series of filters was applied to all of the source data prior to analysis. First, any storage values that were outside of an operational range (i.e., the minimum and maximum capacities of the reservoir) were flagged for further examination. The majority of these cases were sensor failures indicated by numerical error codes, obvious decimal place errors, or obvious errors in units because they were different than the remaining data for that waterbody. If a value was missing, or the source of the error could not be positively identified, the datum was excluded. In some cases, the resulting data gaps could be filled by referencing alternative sensors from the same reservoir. Finally, the completeness of each record was assessed and water years missing > 15\% of records were excluded.

To examine the potential effects of timing of water level fluctuations on fish $\mathrm{THg}$ concentrations, reservoirs were classified based upon the month in which they typically reached their annual minimum storage during the five-years prior to each fish collection event (Figure 1a). Water level fluctuations were also calculated for each water year in which at least three fish were sampled from a reservoir and sufficient storage data existed. Within-year water storage fluctuations were calculated as the difference between the minimum and maximum monthly storage levels within a water year (Figure 1b) and converted to estimates of the proportional 
within-year change in water storage by normalizing with the minimum monthly storage for the year. This within-year change in reservoir water storage represents the relative area of sediments that have been exposed for less than one year, and are inundated upon reservoir filling. Betweenyear change in maximum water storage was also calculated as a proxy for the relative area of sediment that was re-inundated after being exposed for more than one year. Between-year change in reservoir water storage was calculated as the difference between maximum water storage in the sampling year and the previous year (Figure 1c), converted to proportional estimates of between-year change in water storage by normalizing with the maximum storage of the previous year. Both within- and between-year fluctuations in water storage levels were averaged over the five-year period prior to fish collections except in a few cases where a threeor four-year period was used instead due to incomplete water level data for some waterbodies. 
Willacker et al. Mercury in Western Reservoirs
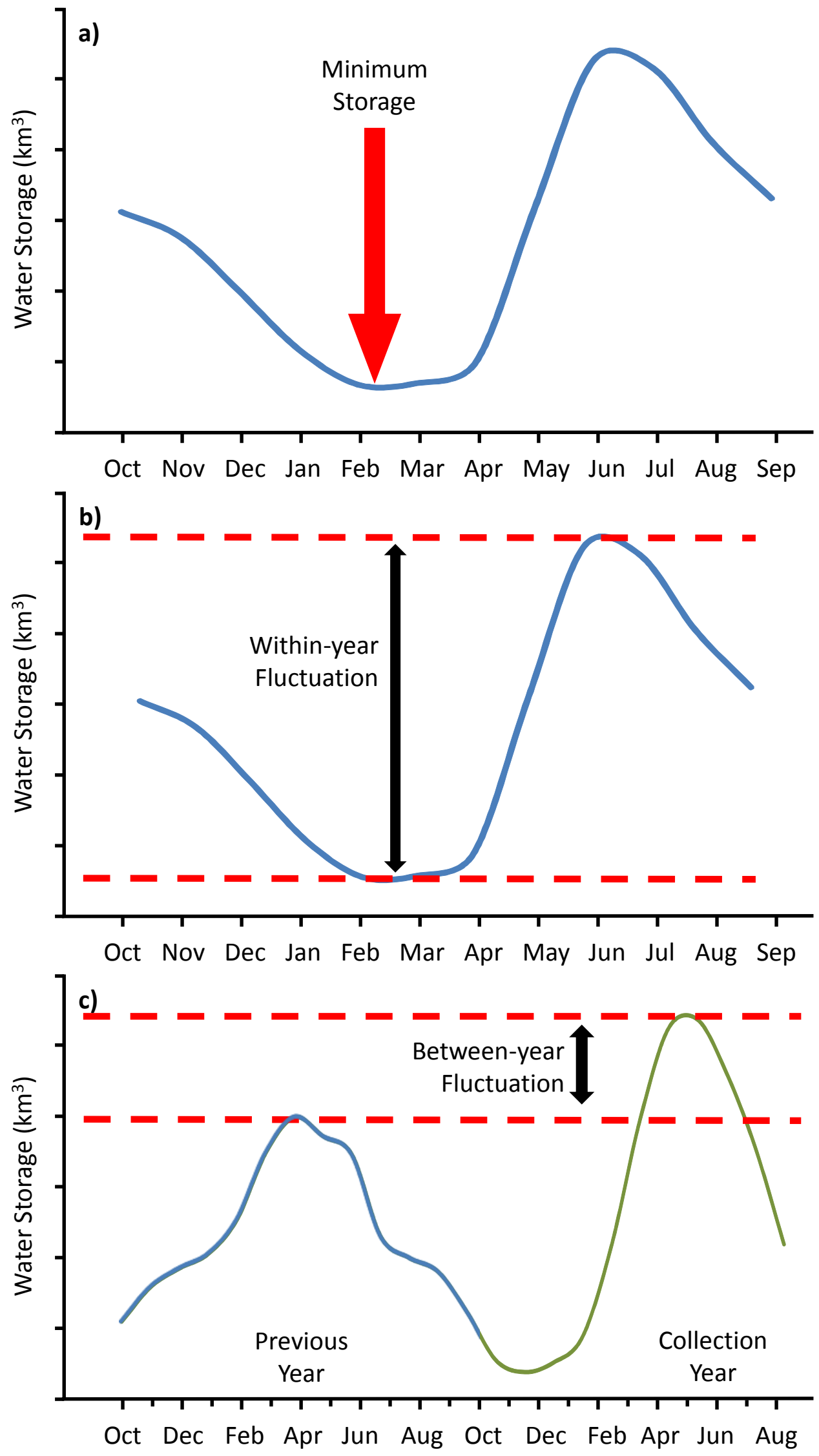
Figure 1: Conceptual diagram detailing the calculation of three water management parameters: a) timing of minimum water storage; b) within-year change in water storage; and c) betweenyear change in water storage. All three parameters were averaged over the five-years preceding each fish collection.

\subsection{Statistical Analysis}

The programs JMP® (version 12.0.1; SAS Institute Inc.) and R (version 3.1.0; www.rproject.org) were used for statistical analysis of size adjusted and natural-log transformed fish $\mathrm{THg}$ concentrations $(\mu \mathrm{g} / \mathrm{g} \mathrm{ww})$. Unless otherwise specified, results are presented as backtransformed least-squares means with standard errors estimated using the delta method (Williams et al., 2002).

Differences in fish $\mathrm{THg}$ concentrations between lakes and reservoirs were assessed using a linear mixed-effects model with habitat (reservoir or lake) and ecoregion as fixed effects; waterbody, species, and sampling year as random effects; and a habitat $\times$ ecoregion interaction. This model was contrasted with three similar models for subsets of the data to assess potential biases due to 1) the inclusion of rare taxa, 2) variation in background contamination, and 3) the influence of waterbody size. The first alternative was the same as the selected model but only included data for species with data from at least 15 sites. The second alternative included soil $\mathrm{THg}$ concentrations interpolated from point data (Smith et al., 2013) as a covariate. The third alternative analysis included waterbody surface area as a covariate and an interaction between surface area and habitat. In all three alternatives, the results were similar to those of the simpler model using the full dataset (Table S2); therefore, the full dataset was used and neither soil $\mathrm{THg}$ nor waterbody surface area was included as a covariate.

The influence of reservoir age on fish $\mathrm{THg}$ concentrations was assessed using a linear mixedeffects model that included ecoregion and reservoir age as categorical fixed effects; with waterbody, species, and sampling year as random effects. A segmented regression (Toms and Lesperance, 2003) followed by a Davies test (Piepho and Ogutu, 2003) was also employed to identify potential breakpoints in the relationship between fish $\mathrm{THg}$ concentrations and reservoir age after accounting for the effects of ecoregion, waterbody, species, and sampling year.

A subset of the data was used to examine the effects of water level management on fish $\mathrm{THg}$ concentrations in reservoirs. First, data were analyzed in a single linear mixed-effects model with 
ecoregion and month the minimum storage level occurred as fixed effects; within- and betweenannual changes in water storage as covariates; and waterbody and species as random effects. The effects of water management could differ among ecoregions, but interactions could not be included in the above global model, because not all months were represented as water storage minimums in each ecoregion. Therefore, ecoregion-specific models were subsequently used to examine the influence of water level management on fish $\mathrm{THg}$ concentrations in individual ecoregions.

\section{Results and Discussion}

\subsection{Reservoirs versus Non-Impounded Lakes}

A total of 64386 fish $\mathrm{THg}$ concentrations were complied, representing 157 species from 883 reservoirs and 1387 lakes throughout the western United States and Canada (Table 2). Across all ecoregions, species, waterbodies, years, and fish sizes, geometric mean $\mathrm{THg}$ concentrations $(\mu \mathrm{g} / \mathrm{g}$ ww \pm standard error) in skinless boneless fish fillet was $0.23 \pm 0.001(\mathrm{n}=$ $27,007)$ in reservoirs compared to $0.17 \pm 0.001$ in lakes $(n=37,379)$. Records lacking length data or from waterbodies with total sample sizes of less than three individuals $(n=4,534)$ were excluded from subsequent analyses.

After accounting for the influence of species, waterbody, year, and ecoregion, size-adjusted least squares mean fish $\mathrm{THg}$ concentrations were $44 \%$ higher in reservoirs than lakes (reservoirs $=0.13 \pm 0.011$, lakes $=0.09 \pm 0.006, \mathrm{~F}_{1,2146}=22.59, \mathrm{P}<0.001$; Figure 2); however, the significant interaction between ecoregion and habitat $\left(\mathrm{F}_{6,2917}=9.23, \mathrm{P}<0.001\right)$ indicated that the difference between lakes and reservoirs was not consistent among ecoregions. In individual ecoregions, fish $\mathrm{THg}$ concentrations ( $\mu \mathrm{g} / \mathrm{g}$ wW \pm standard error) differed between reservoirs and lakes in Mediterranean California (reservoirs $=0.15 \pm 0.013$, lakes $=0.07 \pm 0.008, P<0.001$ ), North American Deserts (reservoirs $=0.14 \pm 0.011$, lakes $=0.09 \pm 0.009, \mathrm{P}<0.001$ ), and Northern Forests (reservoirs $=0.16 \pm 0.059$, lakes $=0.08 \pm 0.006, \mathrm{P}=0.003$ ) ecoregions (Figure 2). Least squares mean fish $\mathrm{THg}$ concentrations also tended to be higher in reservoirs than in lakes from Taiga ecoregion (reservoirs $=0.18 \pm 0.067$, lakes $=0.10 \pm 0.009$; Figure 2 ), though the difference was not statistically significant $(\mathrm{P}=0.14)$. Fish $\mathrm{THg}$ concentrations were similar between reservoirs and lakes of the Great Plains (reservoirs $=0.13 \pm 0.009$, lakes $=0.12 \pm 0.010$, 
$\mathrm{P}=0.62$ ), Marine West Coast Forest (lake $=0.13 \pm 0.013$, reservoir $=0.11 \pm 0.022, \mathrm{P}=0.60$ ), and Northwestern Forested Mountains (lake $=0.11 \pm 0.008$, reservoir $=0.12 \pm 0.009, P=0.24$ ) ecoregions (Figure 2).

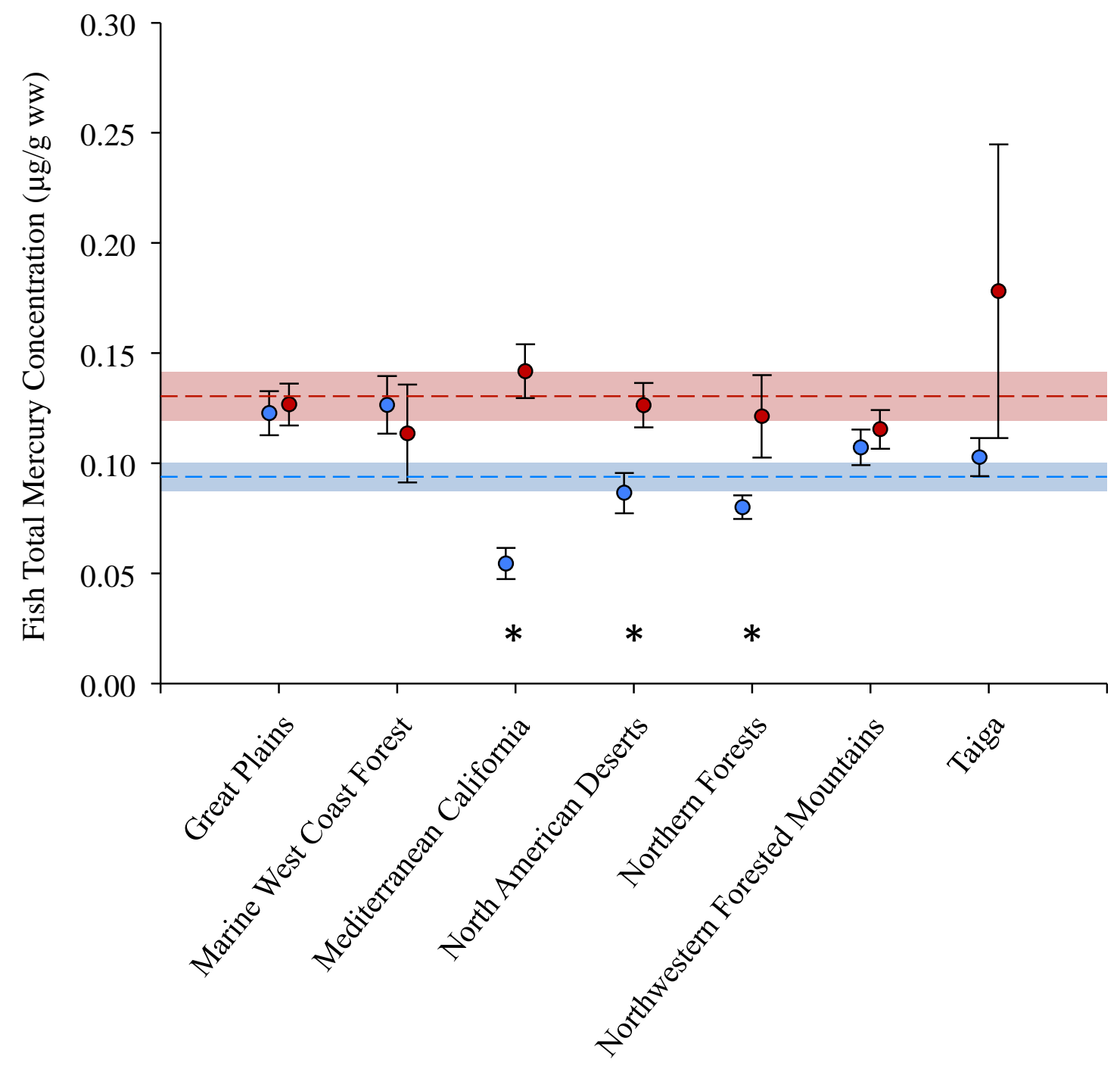

Figure 2: Least squares mean total mercury concentrations ( $\mu \mathrm{g} / \mathrm{g} w \mathrm{w} \pm$ standard error) in sizestandardized fish from reservoirs (red-darker grey) and non-impounded lakes (blue) in the western United States and Canada. Points are least squares means for individual ecoregions whereas dashed lines are the global least squares means (shaded area is standard error) across all ecoregions. Least squares mean account for the effects of ecoregion (global least squares means only), species, waterbody, and sampling year. Ecoregions where reservoirs and non-impounded lakes were significantly different $(\mathrm{P}<0.05)$ are marked with an asterisk. 
Fish THg concentrations were 1.5, 1.6, and 2.6-fold higher in reservoirs than non-impounded lakes in the North American Deserts, Northern Forests, and Mediterranean California ecoregions, respectively. Similar differences (1.7-fold) were observed between reservoirs and lakes in the Taiga ecoregion though these differences were not significant, likely due to the small number of reservoirs with data from this ecoregion (Table 2). These differences are within the range of those found in other comparisons of reservoirs and lakes in several areas. For example, fish $\mathrm{THg}$ concentrations from eight recently flooded reservoirs in northern Manitoba were 1.6- to 8.9-fold higher than from nearby lakes (Bodaly et al., 1984; Bodaly et al., 2007), and fish from 11 Finnish reservoirs had $\mathrm{THg}$ concentrations 1.4- to 3.5-fold higher than those in fish from reference lakes (Lodenius et al., 1983). Although the differences observed in the current study are on the lower end of these ranges, our analysis included reservoirs ranging in age from $<1$ year to nearly 160 years old, whereas the majority of reservoirs in the prior studies were less than two decades old. This difference in reservoir age may be particularly important considering the temporal dynamics of fish $\mathrm{THg}$ concentrations associated with reservoir creation and ageing (discussed further below). In fact, fish $\mathrm{THg}$ concentrations from reservoirs less than 12 years old were significantly higher than concentrations in lakes for all ecoregions $\left(\mathrm{F}_{1,1107}=25.22, \mathrm{P}<0.001\right)$.

These differences in fish $\mathrm{Hg}$ concentrations between habitats likely translate into increased risk to fish, wildlife, and human consumers utilizing fish from reservoirs versus lakes. Across all ecoregions, $44 \%$ of individual fish $\mathrm{THg}$ concentrations from reservoirs exceeded the US EPA benchmark for safe consumption $(0.3 \mu \mathrm{g} / \mathrm{g} \mathrm{ww})$ compared to $31 \%$ for non-impounded lakes. However, 50\% of fish from reservoirs in the North American Deserts, Northern Forests, and Mediterranean California ecoregions exceeded the EPA benchmark compared to only $20 \%$ of fish from non-impounded lakes in these regions. This is similar to findings from Finland where $66 \%$ of fish sampled from reservoirs exceeded the Finnish consumption benchmark $(0.5 \mu \mathrm{g} / \mathrm{g}$ ww) compared to $35 \%$ of fish from natural lakes (Porvari, 1998).

This is the first study with sufficient spatial breadth to compare fish $\mathrm{THg}$ concentrations from reservoirs and lakes across multiple ecoregions. The factors responsible for the variation in the differences between reservoirs and lakes among ecoregions are unclear, but it is unlikely that they result from inherent bias in the dataset. Despite variation in the fish species represented in each ecoregion, foraging guilds and average trophic position of fishes were similar among reservoirs and lakes both within and among ecoregions (guild and trophic position of each 
species were based on ecological data reported in FishBase; Froese and Pauly, 2003) (Table S3). Similarly, reservoir ages did not differ among ecoregions where fish $\mathrm{THg}$ concentrations were higher in reservoirs than in lakes (median $=42$ years) and ecoregions with no difference in fish $\mathrm{THg}$ concentrations between habitats (median $=43$ years). Rather, regional variation in $\mathrm{Hg}$ deposition (Weiss-Penzias et al., 2016), sedimentary MeHg concentrations and loading (Fleck et al., this issue), or other biogeochemical conditions, coupled with differences in climate, reservoir management and basin morphology, likely contribute to the observed variation among ecoregions. Although several studies have examined drivers of differences between boreal reservoirs and lakes (French et al., 1998; Jackson, 1988; Johnston et al., 1991; Verta et al., 1986), these data suggest that quantitative comparisons of drivers among regions is a valuable direction for future research.

\subsection{Reservoir Age Influences on Fish Mercury Concentrations}

Changes in fish THg concentrations following reservoir impoundment is a source of variation among reservoirs that has received considerable previous attention, though typically only in relatively young reservoirs. Reservoirs in this study ranged in age from 0 to 157 years old (postimpoundment) at the time of fish sampling, with some reservoirs completed as recently as 2010. Sampling events were relatively well distributed among reservoirs of varying ages, with the exception of the oldest reservoirs, which tended to be sampled more recently (Table S4). After statistically accounting for the effects of waterbody, species, and sampling year, there was a substantial effect of reservoir age on size-adjusted fish $\mathrm{THg}$ concentrations $\left(\mathrm{F}_{1231,12771}=14.51, \mathrm{P}\right.$ $<0.001$; Figure 3). Segmented regression identified two breakpoints in the relationship between fish $\mathrm{THg}$ concentrations and reservoir age, the first occurred at $3.04 \pm 0.71$ years and the second at $12.48 \pm 1.33$ years (Davies-test, $\mathrm{k}=1000, \mathrm{P}<0.001$; Figure 3). Least squares mean $\mathrm{THg}$ concentrations in fish increased from $0.27 \pm 0.039 \mu \mathrm{g} / \mathrm{g}$ ww in reservoirs less than 1 year old to $0.43 \pm 0.061 \mu \mathrm{g} / \mathrm{g}$ ww in 3 year old reservoirs. Fish THg concentrations in 12 year old reservoirs were similar to those in newly formed ( $<1$ year old) reservoirs and continued to decline slightly with reservoir age thereafter (Figure 3). 


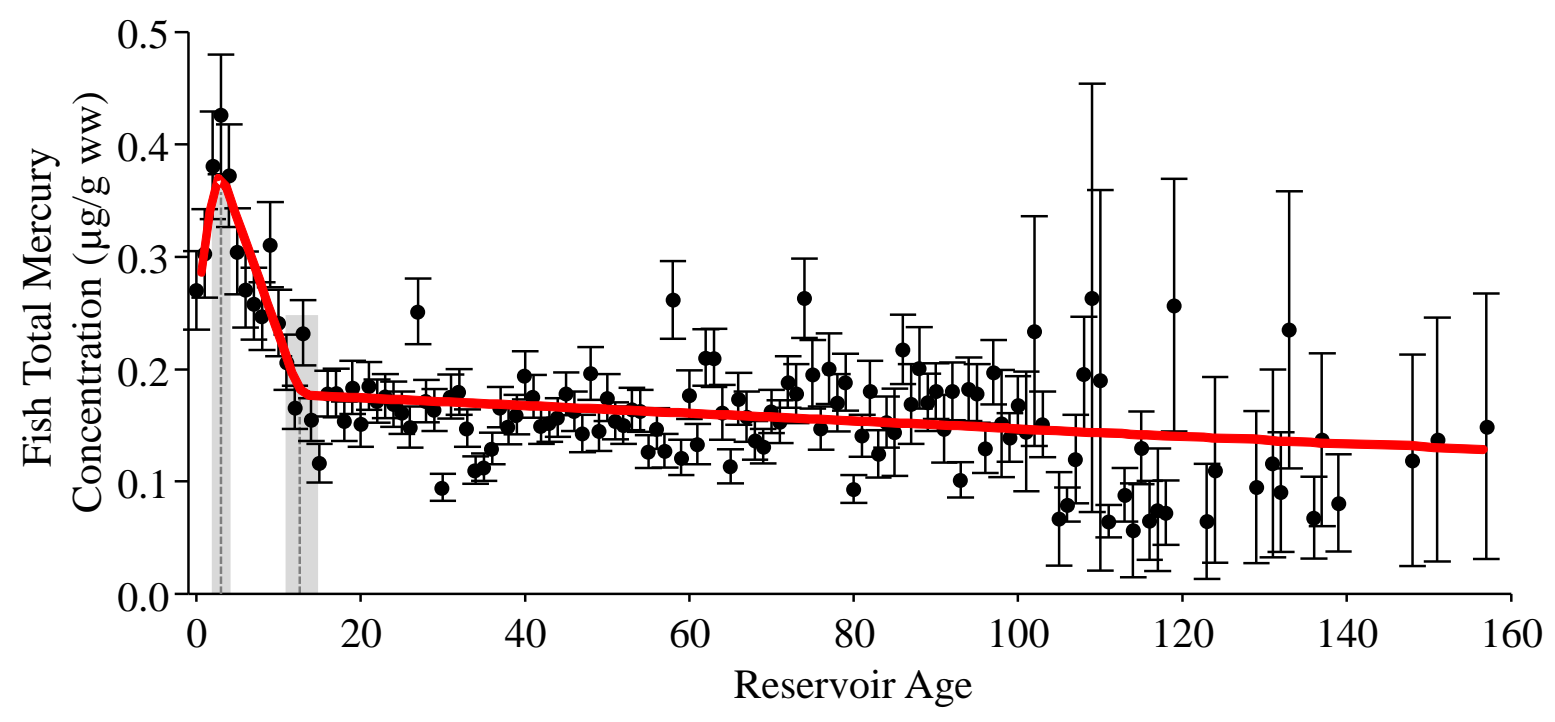

Figure 3: Least squares mean total mercury concentrations ( $\mu \mathrm{g} / \mathrm{g}$ ww \pm standard error) in sizestandardized fish from reservoirs across western North America. Least squares mean account for the effects of ecoregion, waterbody, species, and sampling year. Vertical grey dashed lines and shaded regions indicate estimated breakpoints ( \pm standard error) from segmented linear regression (solid line) on fish mercury concentration when accounting for the effects of ecoregion, waterbody, species, and sampling year.

These data suggest that fish THg concentrations change dramatically in the decade following reservoir creation. The breakpoints in fish $\mathrm{THg}$ trends are consistent with those reported in previous studies of fish $\mathrm{THg}$ concentrations from newly formed reservoirs. Maximum $\mathrm{THg}$ concentrations in fish from eight Manitoban reservoirs sampled within 32 years of impoundment generally occurred between 2 and 8 years following impoundment (Bodaly et al., 2007). Similarly, fish THg concentrations peaked 3-years after impoundment in Finnish reservoirs (Porvari, 1998), within 6 years for most species in Smallwood Reservoir, Labrador (Anderson et al., 1995), and 5-13 years after impoundment in reservoirs of northern Quebec (Schetagne and Verdon, 1999). In these studies, fish $\mathrm{THg}$ concentrations from most species and reservoirs returned to background levels (i.e., within the range of concentrations observed from preimpoundment or non-impounded lakes) within 10-25 years following impoundment (Anderson et al., 1995; Bodaly et al., 2007; Porvari, 1998; Schetagne and Verdon, 1999). However, some reservoirs in each study had not reached background concentrations after 30 or more years, and in some reservoirs in Newfoundland have remained elevated for at least 60 years following impoundment (French et al., 1998). In the current study, fish THg concentrations in reservoirs 
did not generally approach the global least squares mean of non-impounded lakes (Figure 2) for at least a century following impoundment (Figure 3). Thus, although the initial changes in fish $\mathrm{THg}$ concentrations following reservoir impoundment are an important characteristic of $\mathrm{Hg}$ cycling in reservoirs, these data suggest that fish $\mathrm{THg}$ remain elevated even in long-established reservoirs.

\subsection{Water Management Influences on Fish Mercury Concentrations}

Water storage fluctuation data and fish $\mathrm{THg}$ concentrations from for 189 reservoirs, representing 355 sampling events, were analyzed to better understand the processes associated with increased fish $\mathrm{THg}$ concentrations in reservoirs relative to lakes. Specifically, a linear mixed-effects model that accounted for variation due to ecoregion, waterbody, species, and year was used to determine whether fish $\mathrm{THg}$ concentrations were affected by the timing of drawdowns, or within- and between-year water storage fluctuations. Across all ecoregions, the month in which reservoirs reached minimum capacity was an important determinant of fish $\mathrm{THg}$ concentrations $\left(\mathrm{F}_{11,1049}=8.49, \mathrm{P}<0.001\right.$; Figure $\left.\mathrm{S} 2 \mathrm{a}\right)$. Reservoirs with minimum water storage levels occurring between April and July had least squares mean fish THg concentrations that were 1.8 to 3.5 -fold higher than those with typical minimum water storage levels occurring between August and March (Figure S2a). Additionally, the between-year change in maximum water storage had a strong impact on fish $\mathrm{THg}$ concentrations $\left(\mathrm{F}_{1,2453}=27.71, \mathrm{P}<0.001\right.$; Figure S2b), whereas within-year changes between minimum and maximum water level were not correlated with fish $\mathrm{THg}$ concentrations $\left(\mathrm{F}_{1,691}=8.49, \mathrm{P}=0.26\right.$; Figure $\left.\mathrm{S} 2 \mathrm{c}\right)$. In fact, predicted fish THg concentrations increased by 3.2-fold over the range of observed between-year change in maximum water storage, but did not vary over the range of within-year changes in water storage.

Whereas the above model accounts for the effect of ecoregion, the model would not converge with interactions between ecoregion and the water management parameters. Therefore, ecoregion-specific models were used to assess whether water level fluctuations affected fish $\mathrm{THg}$ concentrations differently among ecoregions. The month in which reservoirs reached minimum water storage was a significant predictor of fish $\mathrm{THg}$ concentrations in the Great Plains $\left(\mathrm{F}_{6,40}=\right.$ 5.53, $\mathrm{P}<0.001)$ and North American Deserts $\left(\mathrm{F}_{10,39}=3.05, \mathrm{P}=0.01\right)$ ecoregions after accounting for the effects of between- and within-year water storage fluctuations, waterbody, and 
species. In both of these ecoregions, least squares mean $\mathrm{THg}$ concentrations were lower in reservoirs with minimum water storage occurring in January or February and higher in reservoirs with minimum water storage occurring during March and April (Figure 4). In the North American Deserts this trend continued upwards and reservoirs with minimum water storage occurring during July had fish THg concentrations 13.6-fold higher than reservoirs with minimum water storage occurring in January. Fish THg concentrations were 4.6- and 2.9-fold lower in Great Plains and North American Desert reservoirs with minimum water storage occurring in August than in reservoirs with minimum water storage occurring in July (Figure 4). Least squares mean $\mathrm{THg}$ concentrations followed a similar trend in the Northwestern Forested Mountains ecoregion, where fish THg concentrations increased 1.8-fold between reservoirs with minimum water storage occurring in January and reservoirs with minimum storage occurring in June. Fish THg concentrations then gradually declined in reservoirs with minimum storage levels occurring from September through December $\left(\mathrm{F}_{8,256}=1.85, \mathrm{P}=0.07\right.$; Figure 4). A possible explanation for this pattern is that exposure of sediments during the spring and early summer growing seasons leads to increased growth of early succession, herbaceous vegetation and subsequent accumulation of labile organic matter, which fuels microbial production upon inundation (Larson et al., 2014). Similar differences have been widely observed among recently impounded reservoirs with varying quantities or quality of flooded organic matter (Johnston et al., 1991; Larssen, 2010; Mailman et al., 2006). The current data suggest that a similar process may also occur over much shorter time frames, when reductions in reservoir water levels expose substrate that allows for plant growth within the reservoir boundaries. In the Mediterranean California ecoregion, fish $\mathrm{THg}$ concentrations were not different among reservoirs with water storage minimums that occurred in different months $\left(\mathrm{F}_{7,51}=0.60, \mathrm{P}=0.76\right)$ and there was no apparent pattern in fish $\mathrm{THg}$ concentrations among months (Figure 5). Although months were utilized as the temporal variable in this analysis, it is important to note that individual months do not necessarily correspond to similar conditions in each ecoregion. For example, in much of the Mediterranean California ecoregion maximum growth of terrestrial vegetation on exposed sediments would be expected in the wetter winter months as opposed to summer months. This confounding effect could be avoided by comparing the timing of minimum water levels to remotely sensed phenological indices (Zhang et al., 2003), or preferably to in-situ measurements 
of vegetative production on exposed sediments. Such studies would provide valuable insights into the mechanisms by which water level fluctuations influence fish $\mathrm{THg}$ concentrations.

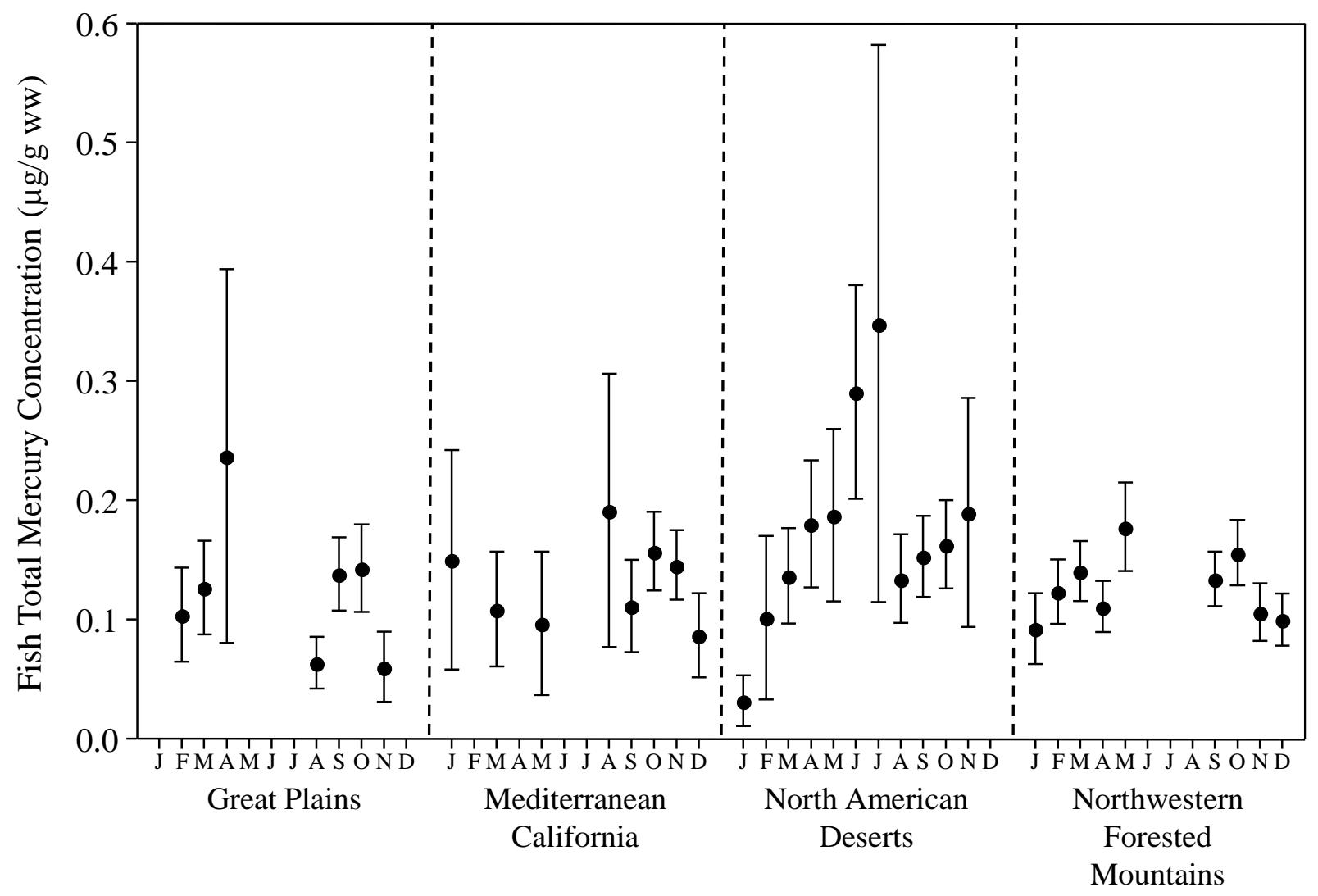

Month of Minimum Water Storage by Ecoregion

Figure 4: Least squares mean total mercury ( $\mathrm{THg}$ ) concentrations ( $\mu \mathrm{g} / \mathrm{g}$ ww \pm standard error) in size-standardized fish from reservoirs with minimum water storage levels occurring in different months. Least squares means account for the effects of within- and between-year changes in water storage levels, waterbody, and species.

The effects of within- and between-year changes in water storage within each ecoregion were examined after accounting for the effects of timing of minimum water storage, waterbody, and species. Fish THg concentrations were positively correlated with between-year differences in maximum water storage in the Great Plains $\left(\mathrm{F}_{1,465}=18.12, \mathrm{P}<0.001\right)$, North American Deserts $\left(\mathrm{F}_{1,870}=32.27, \mathrm{P}<0.001\right)$, and Northwestern Forested Mountains $\left(\mathrm{F}_{1,687}=11.14, \mathrm{P}<0.001\right)$ ecoregions, increasing 2.1 to 3.2-fold between the reservoirs with the smallest and largest 
between-year differences. There was no effect of between-year difference in maximum water storage on fish $\mathrm{THg}$ concentrations in the Mediterranean California ecoregion $\left(\mathrm{F}_{1,298}=0.07, \mathrm{P}=\right.$ 0.787; Figure 5). In contrast, fish THg concentrations were correlated with within-year changes (annual minimum to annual maximum) in water storage in the Northwestern Forested Mountains ecoregion $\left(\mathrm{F}_{1,278}=6.99, \mathrm{P}=0.01\right)$, where fish THg concentrations increased 2.8-fold over the range of within-year fluctuations, but not in any of the other ecoregions (Great Plains: $\mathrm{F}_{1,76}=$ 0.32, $\mathrm{P}=0.57$; Mediterranean California: $\mathrm{F}_{1,123}=0.02, \mathrm{P}=0.866$; North American Deserts: $\mathrm{F}_{1,835}$ $=0.59, \mathrm{P}=0.44$; Figure 6).

Fish THg concentrations were most often correlated with between-year changes in maximum water storage, but rarely with within-year water storage fluctuations. These results are consistent with previous work that found changes in maximum water levels between years were the strongest predictor of THg concentrations in young-of-year Yellow Perch (Perca flavescens) among six different measures of water level fluctuation (Sorensen et al., 2005). Although withinyear wetting and drying cycles can facilitate $\mathrm{MeHg}$ production in sediments (Benoit et al., 2003; Eckley et al., 2015; Snodgrass et al., 2000), it appears that exposure of sediments for longer time periods further exacerbates this process. Exposure of sediments results in re-oxidation of sediments that increases sediment sulfate and subsequently facilitates methylation by sulfate reducing bacteria (Eckley et al., 2015; Selch et al., 2007). Importantly, sediment sulfate concentrations and subsequent $\mathrm{MeHg}$ production are positively correlated with the duration of sediment exposure (Eckley et al., 2015), and are particularly high in sediments that have been exposed for a year or more (Selch et al., 2007). This is an important finding because it suggests that large relative increases in maximum water storage can exacerbate $\mathrm{Hg}$ bioaccumulation in western reservoirs. This is particularly true in the more arid North American Deserts and Great Plains ecoregions. The mechanism underlying differences in the effect of water level fluctuations on fish THg concentrations among ecoregions is unclear, but could be due to differences in shoreline characteristics that result in higher sediment exposure during water level fluctuations (Larson et al., 2014) or differences in organic matter inputs (Hall et al., 2005; Larssen, 2010). In particular, fish $\mathrm{THg}$ concentrations in reservoirs of the Mediterranean California ecoregion appear to be substantially less sensitive to water level fluctuations than reservoirs in other ecoregions. This ecoregion is heavily impacted by legacy mining that has resulted in elevated $\mathrm{MeHg}$ concentrations in large proportion of the lowland reservoirs (Alpers et al., 2005; Davis et 
al., 2010; Stewart et al., 2008). It is possible that such background contamination confounds the effect of water level fluctuations on fish THg concentrations in these systems. Further, the region is subject to one of the most intensive water storage and diversion systems in the world. Because of the high density of reservoirs and prevalence of inter-basin water movements, nearly every reservoir in the region is situated downstream of other reservoirs. Thus, the effects of reservoir water management are likely to be more complex and variably dependent on conditions in reservoirs situated upstream (Bodaly et al., 2007; Johnston et al., 1991; Schetagne et al., 2000). This "downstream effect" can have substantial impacts on fish $\mathrm{THg}$ concentrations, with upstream reservoir conditions explaining $>75 \%$ of the variation in downstream reservoirs, and often more than in-reservoir processes (Johnston et al., 1991). Finally, it cannot be ruled out that the lack of a relationship between water storage fluctuations and fish $\mathrm{THg}$ concentrations in the Mediterranean California ecoregion may stem from a bias in our water fluctuation dataset for this ecoregion. Over $90 \%$ of the water fluctuation data corresponds to reservoirs where fish were sampled during 2007 or 2008, a period when California was experiencing a severe drought (Christian-Smith et al., 2011). 

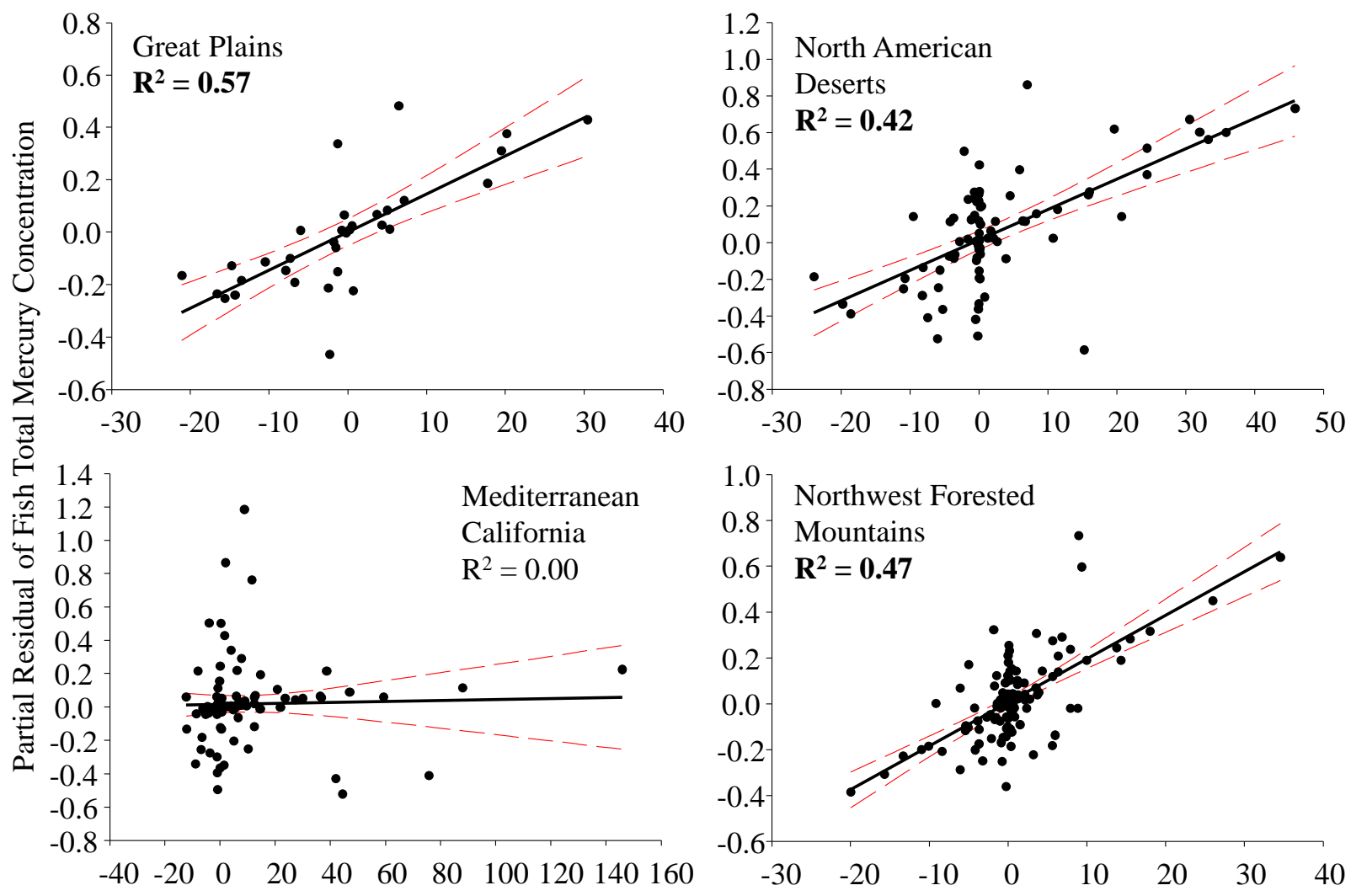

Between-year Change in Maximum Water Storage (\%)

Figure 5: Partial residual plots depicting the relationships between total mercury concentrations in size-standardized fish and between-year changes in maximum water storage from reservoirs in four ecoregions of the western United States. Partial residuals account for the effects of timing of minimum water storage, within-year changes in water storage, waterbody, and species. $\mathrm{R}^{2}$ values that are bolded indicate those ecoregions where between-year changes in maximum water storage were correlated with fish $\mathrm{THg}$ concentrations. 


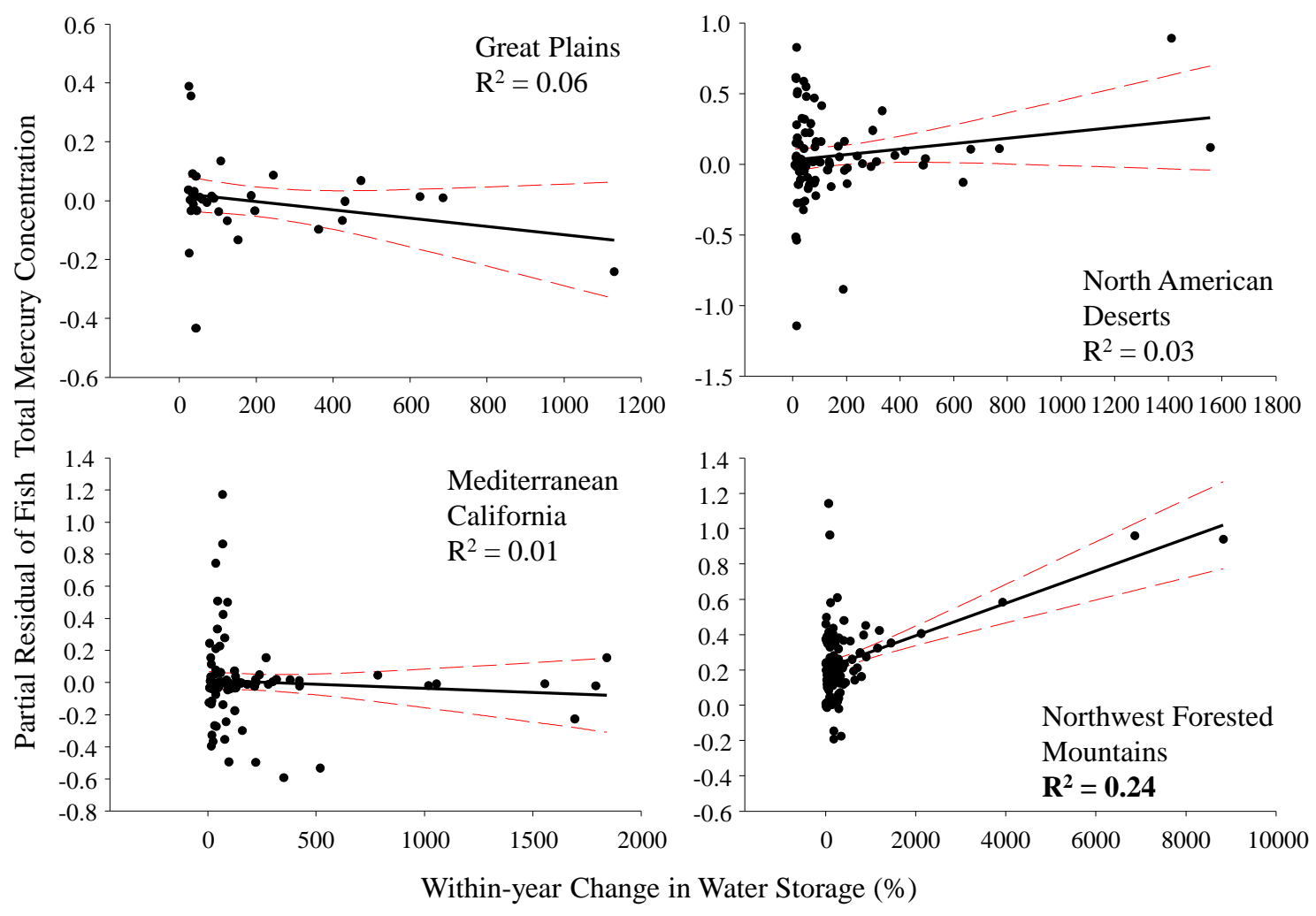

Figure 6: Partial residual plots depicting the relationships between total mercury concentrations in size-standardized fish and within-year changes in water storage from reservoirs in four ecoregions of the western United States. Partial residuals account for the effects of timing of minimum storage, between-year changes in maximum water storage, site, and species. $\mathrm{R}^{2}$ values that are bolded indicate those ecoregions where within-year changes were correlated with fish THg concentrations.

\section{Conclusion}

This study provides the largest spatial and temporal evaluation of fish $\mathrm{THg}$ concentrations in reservoirs to date. By leveraging such an extensive dataset, it is shown that fish $\mathrm{THg}$ concentrations are often higher in reservoirs than non-impounded lakes, and that this relationship varies considerably among ecoregions and age of the reservoir. Importantly, this study did not examine the mechanisms leading to differences among ecoregions, though regional differences in atmospheric $\mathrm{Hg}$ deposition (Weiss-Penzias et al., 2016), reservoir characteristics, and water management practices may play a role. Additionally, fish $\mathrm{THg}$ concentrations in reservoirs are shown to change dramatically with reservoir age, with the more pronounced increases in fish $\mathrm{THg}$ concentrations occurring in the first 3 years after reservoir creation and the larges declines occurring from 3 to 12 years after reservoir impoundment. Thus, management practices that limit 
the magnitude and duration of this peak, such as pre-flooding biomass reduction and extending filling over longer time-frames (Mailman et al., 2006), may substantially reduce MeHg exposure risk in reservoirs. Of particular importance, these data suggest that in some cases water management may provide a means to reduce $\mathrm{MeHg}$ bioaccumulation by manipulating the timing of water storage level minimums. Reducing the amount of sediment exposed (i.e., keeping water levels raised) during the critical spring and summer growing seasons (Jan-Jul) appears to be one mechanism by which fish THg concentrations could be reduced within reservoirs. Whether similar results could be obtained by reducing organic matter accumulation on sediments exposed during this period, or with other treatments, will be of particular interest to managers, especially given increasingly erratic climate patterns which often preclude active management of water levels (Christensen et al., 2004; Pahl-Wostl, 2007). The data also suggests management practices that maintain consistent maximum water levels between years, regardless of the total within-year fluctuation, may be particularly useful for minimizing MeHg bioaccumulation in fish. Although it may be impractical to maintain consistent water levels from one year to the next in the face of increasingly prevalent droughts and unpredictable climate shifts, these results also suggest raising water levels over an extended time period following droughts may have less of an impact than rapid increases in water levels. Future studies examining the biogeochemical and ecological responses to such water management strategies are critical to improving our overall understanding of $\mathrm{Hg}$ cycling and reducing $\mathrm{Hg}$ contamination in fish and wildlife within these important aquatic habitats.

\section{Acknowledgements}

This work was conducted as a part of the Western North American Mercury Synthesis Working Group supported by the John Wesley Powell Center for Analysis and Synthesis funded by the U.S. Geological Survey, with additional support from the U.S. Geological Survey Contaminant Biology Program, National Park Service Air Resources Division, and the US EPA Region 10 RARE Program. We are indebted to the numerous agencies and researchers that donated data to this effort, particularly the Mercury Science Program of Environment Canada, and Linda Campbell, Neil Burgess, and David Depew. Darren Knuteson, Karl Tarbet, Paul Davidson, Kyle Cavalier, and Jesus Hernandez provided particularly valuable assistance obtaining Bureau of Reclamation reservoir storage data, and Michael Stanfill and Kasi Rodgers assisted with the Army Corps of Engineers reservoir data. We would like to thank Patti Haggerty, Branden 
Willacker et al. Mercury in Western Reservoirs

Johnson, Kiira Siitari, Madeline Turnquist, and Clifton Dassuncao for their assistance with data compilation and discussions. The use of trade, product, or firm names in the publication is for descriptive purposes only and does not imply endorsement by the U. S. Government. 
Willacker et al. Mercury in Western Reservoirs

\section{References}

Alpers CN, Hunerlach MP, May JT, Hothem RL. Mercury contamination from historical gold mining in California. 2005.

Anderson MR, Scruton DA, Williams UP, Payne JF. Mercury in fish in the Smallwood Reservoir, Labrador, twenty one years after impoundment. Water, Air, and Soil Pollution 1995; 80: 927-930.

Benoit JM, Gilmour CC, Heyes A, Mason RP, Miller CL. Geochemical and biological controls over methylmercury production and degradation in aquatic ecosystems. In: Cai Y, Braids OC, editors. Biogeochemistry of Environmentally Important Trace Elements. 835. Amer Chemical Soc, Washington, 2003, pp. 262-297.

Bevelhimer MS, Beauchamp JJ, Sample BE, Southworth GR. Estimation of whole-fish contaminant concentrations from fish fillet data. In: U.S. Department of Energy, editor. Office of Environmental Management, Oak Ridge National Laboratory; Oak Ridge, Tennesse, 1997.

Boalt E, Miller A, Dahlgren H. Distribution of cadmium, mercury, and lead in different body parts of Baltic herring (Clupea harengus) and perch (Perca fluviatilis): Implications for environmental status assessments. Marine Pollution Bulletin 2014; 78: 130-136.

Bodaly RA, Hecky RE, Fudge RJP. Increases in Fish Mercury Levels in Lakes Flooded by the Churchill River Diversion, Northern Manitoba. Canadian Journal of Fisheries and Aquatic Sciences 1984; 41: 682-691.

Bodaly RA, Jansen WA, Majewski AR, Fudge RJP, Strange NE, Derksen AJ, et al. Postimpoundment Time Course of Increased Mercury Concentrations in Fish in Hydroelectric Reservoirs of Northern Manitoba, Canada. Archives of Environmental Contamination and Toxicology 2007; 53: 379-389. 
Willacker et al. Mercury in Western Reservoirs

Bunn SE, Arthington AH. Basic principles and ecological consequences of altered flow regimes for aquatic biodiversity. Environmental management 2002; 30: 492-507.

Caldwell CA, Canavan CM, Bloom NS. Potential effects of forest fire and storm flow on total mercury and methylmercury in sediments of an arid-lands reservoir. Science of The Total Environment 2000; 260: 125-133.

Christensen NS, Wood AW, Voisin N, Lettenmaier DP, Palmer RN. The effects of climate change on the hydrology and water resources of the Colorado River basin. Climatic change 2004; 62: 337-363.

Christian-Smith J, Levy M, Gleick PH, Ross N, Luu P. Impacts of the California Drought from 2007 to 2009: Pacific Institute Oakland, CA, 2011.

Clarkson TW, Magos L. The toxicology of mercury and Its chemical compounds. Critical Reviews in Toxicology 2006; 36: 609-662.

Davis J, Melwani A, Bezalel S, Hunt J, Ichikawa G, Bonnema A, et al. Contaminants in fish from California Lakes and reservoirs, 2007-2008: summary report on a two-year screening survey. A Report of the Surface Water Ambient Monitoring Program (SWAMP). California State Water Resources Control Board, Sacramento. Sacramento, CA 2010.

Depew DC, Burgess NM, Anderson MR, Baker R, Bhavsar SP, Bodaly R, et al. An overview of mercury concentrations in freshwater fish species: a national fish mercury dataset for Canada. Canadian Journal of Fisheries and Aquatic Sciences 2013a; 70: 436-451.

Depew DC, Burgess NM, Campbell LM. Modelling mercury concentrations in prey fish: derivation of a national-scale common indicator of dietary mercury exposure for piscivorous fish and wildlife. Environmental Pollution 2013b; 176: 234-243. 
Willacker et al. Mercury in Western Reservoirs

Driscoll CT, Mason RP, Chan HM, Jacob DJ, Pirrone N. Mercury as a global pollutant: Sources, pathways, and effects. Environmental science \& technology 2013; 47: 4967-4983.

Eagles-Smith CA, Ackerman JT, Willacker JJ, Tate MT, Lutz MA, Fleck JA, et al. Spatial and Temporal Patterns of Mercury Concentrations in Freshwater Fishes across the Western US and Canada. Science of the Total Environment 2016a; this issue.

Eagles-Smith CA, Wiener JG, Eckley CS, Willacker JJ, Evers DC, Marvin-DiPasquale M, et al. Mercury in the western U.S. and Canada: Introduction to a synthesis of environmental contamination, fluxes, bioaccumulation, and risk to fish and wildlife. Science of the Total Environment 2016b; this issue.

Eckley C, Luxton T, McKernan J, Goetz J, Goulet J. Influence of reservoir water level fluctuations on sediment methylmercury concentrations downstream of the historical Black Butte mercury mine, OR. Applied Geochemistry 2015; 61: 284-293.

Fleck JA, Marvin-DiPasquale M, Eagles-Smith CA, Ackerman JT, Lutz MA, Tate MT, et al. Mercury and methylmercury in aquatic sediment across western North America. Scien of the Total Environment.

French KJ, Anderson MR, Scruton DA, Ledrew LJ. Fish mercury levels in relation to characteristics of hydroelectric reservoirs in Newfoundland, Canada. Biogeochemistry 1998; 40: 217-233.

Friedl G, Wüest A. Disrupting biogeochemical cycles-Consequences of damming. Aquatic Sciences 2002; 64: 55-65.

Froese R, Pauly D. FishBase. International Center for Living Aquatic Resources Management, 2003. 
Willacker et al. Mercury in Western Reservoirs

Goldstein RM, Brigham ME, Stauffer JC. Comparison of mercury concentrations in liver, muscle, whole bodies, and composites of fish from the Red River of the North. Canadian Journal of Fisheries and Aquatic Sciences 1996; 53: 244-252.

Graf WL. Dam nation: A geographic census of American dams and their large-scale hydrologic impacts. Water Resources Research 1999; 35: 1305-1311.

Grigg NS. Water resources management: Wiley Online Library, 1996.

Hall B, Louis VS, Rolfhus K, Bodaly R, Beaty K, Paterson M, et al. Impacts of reservoir creation on the biogeochemical cycling of methyl mercury and total mercury in boreal upland forests. Ecosystems 2005; 8: 248-266.

Hecky R, Ramsey D, Bodaly R, Strange N. Increased methylmercury contamination in fish in newly formed freshwater reservoirs. Advances in mercury toxicology. Springer, 1991, pp. 33-52.

Jackson TA. The mercury problem in recently formed reservoirs of northern Manitoba (Canada): effects of impoundment and other factors on the production of methyl mercury by microorganisms in sediments. Canadian Journal of Fisheries and Aquatic Sciences 1988; 45: $97-121$.

Johnston TA, Bodaly R, Mathias J. Predicting fish mercury levels from physical characteristics of boreal reservoirs. Canadian Journal of Fisheries and Aquatic Sciences 1991; 48: 14681475.

Kamman NC, Burgess NM, Driscoll CT, Simonin HA, Goodale W, Linehan J, et al. Mercury in freshwater fish of northeast North America-a geographic perspective based on fish tissue monitoring databases. Ecotoxicology 2005; 14: 163-180. 
Willacker et al. Mercury in Western Reservoirs

Kingsford RT. Ecological impacts of dams, water diversions and river management on floodplain wetlands in Australia. Austral Ecology 2000; 25: 109-127.

Larson J, Maki R, Knights B, Gray B. Can mercury in fish be reduced by water level management? Evaluating the effects of water level fluctuation on mercury accumulation in yellow perch (Perca flavescens). Ecotoxicology 2014; 23: 1555-1563.

Larssen T. Mercury in Chinese reservoirs. Environmental pollution 2010; 158: 24-25.

Ligon FK, Dietrich WE, Trush WJ. Downstream ecological effects of dams. BioScience 1995: 183-192.

Lodenius M, Seppänen A, Herranen M. Accumulation of mercury in fish and man from reservoirs in northern Finland. Water, Air, and Soil Pollution 1983; 19: 237-246.

Lucotte M, Schetagne R, Thérien N, Langlois C, Tremblay A. Mercury in the biogeochemical cycle: natural environments and hydroelectric reservoirs of northern Québec (Canada): Springer Berlin, 1999.

Mailman M, Stepnuk L, Cicek N, Bodaly RD. Strategies to lower methyl mercury concentrations in hydroelectric reservoirs and lakes: A review. Science of the Total Environment 2006; 368: 224-235.

Monson B, Staples D, Bhavsar S, Holsen T, Schrank C, Moses S, et al. Spatiotemporal trends of mercury in walleye and largemouth bass from the Laurentian Great Lakes Region. Ecotoxicology 2011; 20: 1555-1567.

Omernik J, Griffith G. Ecoregions of the Conterminous United States: Evolution of a Hierarchical Spatial Framework. Environmental Management 2014; 54: 1249-1266. Pahl-Wostl C. Transitions towards adaptive management of water facing climate and global change. Water resources management 2007; 21: 49-62. 
Willacker et al. Mercury in Western Reservoirs

Piepho HP, Ogutu JO. Inference for the Break Point in Segmented Regression with Application to Longitudinal Data. Biometrical Journal 2003; 45: 591-601.

Poff NL, Hart DD. How dams vary and why it matters for the emerging science of dam removal. Bioscience 2002; 52: 659-668.

Porvari P. Development of fish mercury concentrations in Finnish reservoirs from 1979 to 1994. Science of the Total Environment 1998; 213: 279-290.

Rosenberg DM, McCully P, Pringle CM. Global-scale environmental effects of hydrological alterations: introduction. BioScience 2000; 50: 746-751.

Sabo JL, Bestgen K, Graf W, Sinha T, Wohl EE. Dams in the Cadillac Desert: downstream effects in a geomorphic context. Annals of the New York Academy of Sciences 2012; 1249: 227-246.

Sabo JL, Sinha T, Bowling LC, Schoups GHW, Wallender WW, Campana ME, et al. Reclaiming freshwater sustainability in the Cadillac Desert. Proceedings of the National Academy of Sciences 2010; 107: 21263-21269.

Schetagne R, Doyon J-F, Fournier J-J. Export of mercury downstream from reservoirs. Science of The Total Environment 2000; 260: 135-145.

Schetagne R, Verdon R. Post-impoundment evolution of fish mercury levels at the La Grande Complex, Québec, Canada (from 1978 to 1996). Mercury in the Biogeochemical Cycle. Springer, 1999, pp. 235-258.

Selch TM, Hoagstrom CW, Weimer EJ, Duehr JP, Chipps SR. Influence of Fluctuating Water Levels on Mercury Concentrations in Adult Walleye. Bulletin of Environmental Contamination and Toxicology 2007; 79: 36-40. 
Willacker et al. Mercury in Western Reservoirs

Smith DB, Cannon WF, Woodruff LG, Solano F, Kilburn JE, Fey DL. Geochemical and mineralogical data for soils of the conterminous United States. US Geological Survey Data Series 2013; 801: 19.

Snodgrass JW, Jagoe CH, Bryan J, A Lawrence, Brant HA, Burger J. Effects of trophic status and wetland morphology, hydroperiod, and water chemistry on mercury concentrations in fish. Canadian Journal of Fisheries and Aquatic Sciences 2000; 57: 171-180.

Sorensen JA, Kallemeyn LW, Sydor M. Relationship between mercury accumulation in youngof-the-year yellow perch and water-level fluctuations. Environmental science \& technology 2005; 39: 9237-9243.

St. Louis VL, Rudd JW, Kelly CA, Bodaly R, Paterson MJ, Beaty KG, et al. The rise and fall of mercury methylation in an experimental reservoir. Environmental science \& technology 2004; 38: 1348-1358.

Stewart AR, Saiki MK, Kuwabara JS, Alpers CN, Marvin-DiPasquale M, Krabbenhoft DP. Influence of plankton mercury dynamics and trophic pathways on mercury concentrations of top predator fish of a mining-impacted reservoir. Canadian Journal of Fisheries and Aquatic Sciences 2008; 65: 2351-2366.

Suchanek TH, Eagles-Smith CA, Harner EJ. Is Clear Lake methylmercury distribution decoupled from bulk mercury loading. Ecological Applications 2008; 18: A107-A127.

Toms JD, Lesperance ML. Piecewise Regression: A Tool for Identifying Ecological Thresholds. Ecology 2003; 84: 2034-2041.

Travis W. The Geography of Development and Water in the American West. Research Program on Environment and Behavior. University of Colorado at Boulder, Institute of Behavioral Science 2003; 51. 
Willacker et al. Mercury in Western Reservoirs

US Bureau of Reclemation. Water measurement manual: A guide to effective water measurement practices for better water management: US Department of the Interior, 2001.

Verta M, Rekolainen S, Kinnunen K. Causes of increased fish mercury levels in Finnish reservoirs. 1986.

Weiss-Penzias PS, Gay DA, Brigham ME, Parsons MT, Gustin MS, ter Schure A. Trends in mercury wet deposition and mercury air concentrations across the US and Canada. Science of The Total Environment 2016.

Wiener JG, Martini RE, Sheffy TB, Glass GE. Factors influencing mercury concentrations in walleyes in northern Wisconsin lakes. Transactions of the American Fisheries Society 1990; 119: 862-870.

Williams BK, Nichols JD, Conroy MJ. Analysis and management of animal populations: Academic Press, 2002.

Zhang X, Friedl MA, Schaaf CB, Strahler AH, Hodges JC, Gao F, et al. Monitoring vegetation phenology using MODIS. Remote sensing of environment 2003; 84: 471-475. 
Willacker et al. Mercury in Western Reservoirs

Table 1: Data sources for reservoir fluctuation data, number of reservoirs with fluctuation data, and years utilized in fluctuation analysis.

\begin{tabular}{|c|c|c|c|}
\hline Data Source & $\mathrm{N}$ & \# Sites & Years \\
\hline Army Corp of Engineers - Northwest Division ${ }^{1}$ & 1127 & 11 & $1969-2011$ \\
\hline California Data Exchange Center ${ }^{2}$ & 2005 & 113 & $1965-2011$ \\
\hline \multicolumn{4}{|l|}{ U.S. Bureau of Reclamation } \\
\hline Great Plains Region ${ }^{3}$ & 999 & 28 & $1967-2012$ \\
\hline Pacific Northwest Region ${ }^{4}$ & 334 & 25 & $1965-2011$ \\
\hline Upper Colorado Region ${ }^{5}$ & 419 & 12 & 1983-2011 \\
\hline \multicolumn{4}{|c|}{${ }^{1}$ http://www.nwd-wc.usace.army.mil/cgi-bin/dataquery.pl } \\
\hline \multicolumn{4}{|c|}{2 http://cdec.water.ca.gov/reservoir.html } \\
\hline \multicolumn{4}{|l|}{3 http://www.usbr.gov/gp/hydromet } \\
\hline \multicolumn{4}{|l|}{${ }^{4}$ http://www.usbr.gov/gp/hydromet } \\
\hline 5 http://www.usbr.gov/rsvrWater/fac & & & \\
\hline
\end{tabular}

Table 2: Number of sites and sample sizes for fish from reservoirs and lakes in 10 ecoregions in the western United States and Canada.

\begin{tabular}{lcccc}
\multicolumn{1}{c}{ Ecoregion } & \multicolumn{2}{c}{ Reservoirs } & \multicolumn{2}{c}{ Lakes } \\
& \# Sites & N & \# Sites & N \\
\hline \hline Great Plains & 240 & 11398 & 149 & 4632 \\
Marine West Coast Forest & 17 & 1198 & 72 & 986 \\
Mediterranean California & 139 & 3115 & 59 & 679 \\
North American Deserts & 194 & 4999 & 84 & 606 \\
Northern Forests & 6 & 1059 & 567 & 19259 \\
Northwestern Forested Mountains & 251 & 4288 & 280 & 3804 \\
Southern Semiarid Highlands & 6 & 213 & 1 & 3 \\
Taiga & 3 & 291 & 139 & 6579 \\
Temperate Sierras & 27 & 446 & 3 & 13 \\
Tundra & 0 & 0 & 33 & 818 \\
\hline \hline
\end{tabular}




\section{Graphical Abstract:}

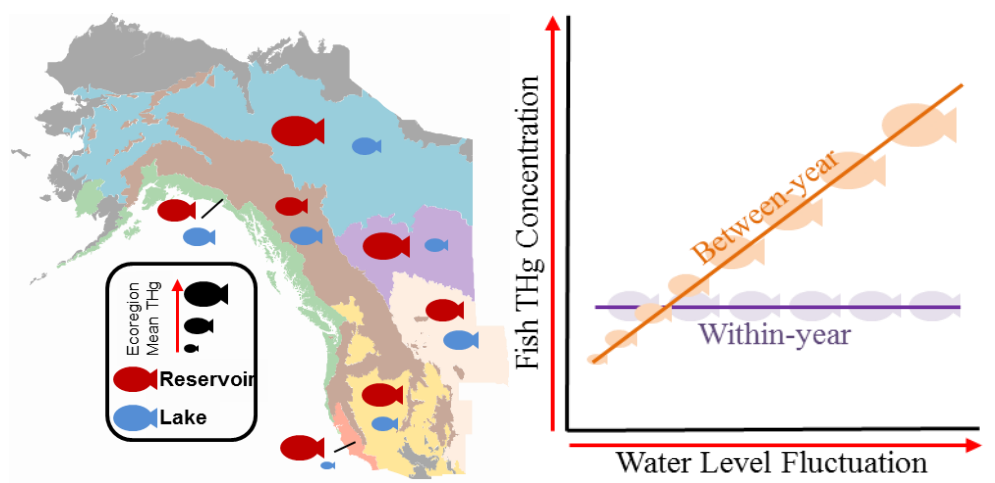

